\title{
Integrated Management of Leafy Spurge-Infested Rangeland
}

\author{
James S. Jacobs, ${ }^{1}$ Roger L. Sheley, ${ }^{2}$ and John J. Borkowski $i^{3}$ \\ Authors are ${ }^{1}$ Invasive Species Specialist, USDA-Natural Resources Conservation Service, Bozeman, MT 59715; \\ ${ }^{2}$ Rangeland Weed Ecologist, USDA-Agricultural Research Service, Eastern Oregon Agricultural Research Center, \\ Burns, OR 97720; and ${ }^{3}$ Professor of Statistics, Montana State University, Bozeman, MT 59717.
}

\begin{abstract}
Leafy spurge is an invasive Eurasian weed on pastures and rangeland in North America where it reduces grass forage production. Our objective was to determine the effects of multispecies grazing combined with Aphthona flea beetles on leafy spurge-infested rangeland. On two western North Dakota sites divided into four 25- to 79-ha pastures, two grazing duration treatments were applied: season-long with 7 to 10 cow calf pairs and 20 to 25 sheep from late May through mid-September, and rotation with 18 to 21 cow calf pairs and 45 to 50 sheep for 3 weeks twice per year. Grazing treatments started in 1998 and continued through 2002. Aphthona spp. were released beginning in 1991 and were widespread in both pastures by 1998. Four grazing exclosures were randomly located in each pasture in the spring of 1998. Cover of leafy spurge, grass, and forbs, as well as density of vegetative and flowering leafy spurge stems were measured in July 1998 through 2002. Aphthona densities were counted July 1999 through 2002. Grazing initially increased leafy spurge vegetative stem density, but grazing decreased vegetative stem density from 104 in 1999 to 20 stems $\cdot \mathrm{m}^{-2}$ in 2002. Season-long grazing reduced vegetative stem density by over 30 stems $\cdot \mathrm{m}^{-2}$ compared to rotation grazing. Leafy spurge flowering stems decreased from 80 stems $\cdot \mathrm{m}^{-2}$ in 1998 to 4 stems $\cdot \mathrm{m}^{-2}$ in 2002 in all treatments. The decrease was more rapid when grazing was combined with Aphthona. Initially, Aphthona densities were greater in the grazed areas than the exclosures, but by 2002 more Aphthona were found in the exclosures than the grazed areas. Grazing reduced grass cover and increased forb cover. Results suggest combining multispecies grazing and Aphthona when restoring spurge-infested grasslands produces a synergistic effect.
\end{abstract}

\section{Resumen}

"Leafy spurge" es una maleza originaria de Eurasia que invade praderas y pastizales de Norteamérica en los que reduce la producción de forraje. Nuestro objetivo fue determinar los efectos del apacentamiento de multiespecies combinado con escarabajos pulga (Aphthona) sobre un pastizal infestado con "Leafy spurge." En dos sitios del oeste de North Dakota, divididos en 4 potreros de 25 a 79 hectáreas, se aplicaron dos tratamientos de duración del apacentamiento: 1) toda la estación con 7 a 10 pares de vaca-becerro y entre 20 y 25 ovinos de fines de Mayo a mediados de Septiembre y 2) rotación con 18 a 21 pares de vaca-becerro y de 45 a 50 ovinos por tres semanas dos veces del año. Los tratamientos de apacentamiento iniciaron en 1998 y continuaron hasta el 2002. Las especies de Aphthona spp fueron liberadas a inicios de 1991, y en 1998 estaban dispersas en ambos potreros. En la primavera de 1998, en cada potrero, se localizaron en forma aleatoria cuatro exclusiones al apacentamiento. De Julio de 1998 al 2002 se midió la cobertura de "Leafy spurge," zacates y hierbas, así como la densidad de tallos florales y vegetativos del "Leafy spurge." Las densidades de Aphthona se contaron de Julio de 1999 al 2002. Inicialmente el apacentamiento incrementó la densidad de tallos vegetativos del "Leafy spurge," sin embargo, posteriormente los disminuyó de 104 en 1999 a 20 tallos $\cdot \mathrm{m}^{-2}$ en el 2002. El apacentamiento durante toda la estación redujo la densidad de tallos vegetativos en 30 tallos $\cdot \mathrm{m}^{-2}$ en comparación con el apacentamiento rotacional. En todos los tratamientos los tallos florales de "Leafy spurge" disminuyeron de 80 tallos $\cdot \mathrm{m}^{-2}$ en 1998 a 4 tallos $\cdot \mathrm{m}^{-2}$ en 2002. La disminución fue más rápida cuando el apacentamiento fue combinado con Aphthona. Al principio las densidades de Aphthona fueron mayores en las áreas apacentadas que en las exclusiones, pero para el 2002 se encontraron más en las exclusiones que en las áreas apacentadas. El apacentamiento disminuyó la cobertura de los zacates e incrementó la de las hierbas. Los resultados sugieren que para restaurar áreas infestadas con "Leafy spurge" el apacentamiento de multiespecies combinado con Aphthona produce un efecto sinergético.

Key Words: Aphthona flea beetles, cattle, sheep, Euphorbia esula, multispecies grazing, successional weed management

\section{INTRODUCTION}

Integrated management of leafy spurge (Euphorbia esula L.) is the application of management strategies in a mutually supportive manner (Walker and Buchanan 1982) that effectively suppresses the weed while encouraging the fitness of desired

Research was funded in part by USDA-ARS, TEAM Leafy Spurge.

Correspondence: James Jacobs, USDA-NRCS, Bozeman, MT 59715. Email: jim. jacobs@mt.usda.gov

Manuscript received 1 December 2005; manuscript accepted 7 June 2006. species. Sheley et al. (1996) proposed using a successional theory as a framework for integrating weed management strategies. Their hypothesis was that communities are dynamic and by integrating management to modify the causes of succession, site availability, species availability, and species performance (Picket et al. 1987), managers can direct a weed-dominated plant community toward domination by desired plant species. This theory fits the weed management needs of low economic value, yet high ecological value, range and wildlands because it employs natural processes during restoration. Understanding how management strategies applied alone and in combination affect site availability, species availability, and species 
performance within the plant community may help develop integrated weed management.

Like most invasive plants, leafy spurge has inherent characteristics that challenge the sustainability of management. Leafy spurge plants produce many seeds, averaging 140 per plant (Lajeunesse et al. 1999), and the seeds can remain viable for 8 years or longer (Bowes and Thomas 1978). The extensive rhizomes of leafy spurge can reach $5 \mathrm{~m}$ from the parent plant and have carbohydrate reserves that sustain the plant after herbicide, cultural, grazing, and biological control management (Raju et al. 1963; Marrow 1979). Vegetative buds on rhizomes enable leafy spurge to spread from roots after disturbance. Weed management that reduces seed production (availability) and vegetative production (performance) of leafy spurge over time will likely be able to sustain leafy spurge control.

Grazing by domestic sheep (Ovis aries) and goats (Capra hircus) has been used to reduce leafy spurge seed availability and performance. Johnston and Peake (1960) found that grazing by sheep reduced leafy spurge basal area and increased crested wheatgrass basal area. Lacey and Sheley (1996) found that highintensity, short-duration sheep grazing applied alone and in combination with the herbicide picloram (4-amino-3,5,6-trichloropicolinic acid, potassium salt) reduced leafy spurge density. Goat grazing and combining goat grazing with cattle (Bos taurus) grazing reduced leafy spurge stem densities 29\% and 25\%, respectively (Prosser 1994). Prosser (1994) also found a $47 \%$ increase in grass production where goats and cattle were grazed together, as compared to a $28.1 \%$ increase where only cattle grazed. Dahl (1999) found that sheep grazing alone, but not sheep combined with cows, reduced leafy spurge stem densities. In that study, no differences in leafy spurge densities were detected between sheep and cows grazing pastures for the entire growing season (season-long) and sheep and cows rotated through pastures twice during the growing season (Dahl 1999). Multiple grass defoliations increased weed establishment (Jacobs and Sheley 1997; Jacobs and Sheley 1999) and season-long grazing may increase the chance of grass being grazed more than rotation grazing. Alternately, utilization of grass more than once may be expected using rotation grazing as compared to seasonlong grazing. Grazing affects species performance and may be a disturbance that affects successional dynamics by increasing bare ground, decreasing litter cover, and influencing soil microflora and microfauna (Bardgett and Wardle 2003).

Biological control insects have been successful in suppressing leafy spurge seed and biomass production. Six species of Aphthona flea beetles are well established in North America and provide control of leafy spurge on many sites (Lym 1998). Adult flea beetles feed on the leaves and flowers, which reduces photosynthesis and seed production. Aphthona larvae feed on root hairs and young roots, reducing water and nutrient uptake and depleting root carbohydrate reserves (Rees et al. 1996). Kirby et al. (2000) found Aphthona reduced cover, density, and yield of leafy spurge and increased grass yield. Beck and Rittenhouse (2000) found Aphthona and sheep grazing compatible for management of leafy spurge, and Hansen (1993) stated sheep grazing and Aphthona nigriscutis "appeared to have reduced leafy spurge stem densities more than either agent acting alone." However, flea beetles do not always establish (Rees 1994) and their impact on leafy spurge varies from site to site and year to year (Lym 1998).
Our objective was to determine the effect of 2 durations of moderate grazing by cattle and sheep on leafy spurge flowering and vegetative stem density, as well as the cover of leafy spurge, grass, forbs, litter and bare ground on rangeland where Aphthona flea beetles have been released for several years. We hypothesized that combining cattle and sheep grazing with flea beetles would cause a greater decrease in spurge density and cover than Aphthona alone, and that shorter duration, higher intensity of rotation grazing would have a greater impact on spurge and desirable plants than the longer duration, lower intensity season-long grazing. We also hypothesized that this combination of ungulate and insect grazers would increase grass, other forbs, and bare ground cover, and decrease plant litter cover more than the insects alone.

\section{MATERIALS AND METHODS}

The study was conducted from 1998 to 2002 on 2 sites in western North Dakota, USA. Site 1 was 257 ha and Site 2 was 200 ha. Each site was divided into 4 pastures to accommodate the 2 durations of grazing treatments by cattle combined with sheep (season-long and twice-over rotation grazing). Both sites were classified as Agropyron smithii/Stipa comata habitat type (Barker and Whitman 1989) with a $40 \%$ to $50 \%$ infestation of leafy spurge (Johnson et al. 2002). Applications of picloram at $0.9 \mathrm{~kg}$ acid equivalent $\cdot \mathrm{ha}^{-1}$ were used to manage leafy spurge prior to 1991.

The release of Aphthona flea beetles on the study began in 1991. At Site 1, 500 A. nigriscutis insects were released and 500 each of $A$. nigriscutis and A. flava were released in 1993. In 1994, 13200 and 17500 A. nigriscutis insects were released at Site 1 and Site 2, respectively. In 1995, 10000 A. nigriscutis insects were released at Site 1 , and a mix of $25000 \mathrm{~A}$. czwalinaellacertosa and $A$. nigriscutis insects were released at Site 2. At Site 2 in 1996, 45000 A. czwalinaellacertosa were released. In 1997 at Site 1, 60000 A. czwalinaellacertosa were released. At Site 1 in 1998, over one million A. czwalinael lacertosa were released. The insects were uniformly distributed across both sites by 1998 .

Two durations of multispecies grazing treatments using Hereford-Angus cross cow calf pairs and mature white-faced ewes were initiated in 1998 and continued through 2002. The duration treatments were season-long grazing and twiceover rotation grazing (hereafter referred to as rotation). Each site was divided into 4 pastures, and one pasture was randomly selected for the season-long grazing treatment. The remaining 3 pastures were used for the rotation grazing treatment. At Site 1, the season-long pasture was $47 \mathrm{ha}$, and the rotation pastures were 79, 61, and 69 ha. The season-long pasture at Site 2 was 44 ha, and the rotation pastures were 37,25 , and 41 ha.

Cattle grazed the season-long pastures from 1 June through 15 September starting in 1998 and continuing through 2002 with 7 to 10 cow calf pairs. Sheep grazed from 15 May through 15 September stocked with 20 to 25 sheep, which was $40 \%$ of carrying capacity without adjustments to cattle numbers. Stocking rates for the rotation pastures were 18 to 21 cow calf pairs and 45 to 50 sheep for 3 weeks, twice per year (Johnson et al. 2002). Cattle and sheep were rotated simultaneously, grazing $40 \%$ of the available carrying capacity in the 
first rotation and $60 \%$ in the second rotation each year. Stocking rates for both grazing treatments were 0.28 and 0.31 AUMs per acre for cattle and sheep, respectively.

To test the effect of grazing on the plant community, 4 grazing exclosures $(4.5 \times 4.5 \mathrm{~m})$ were constructed at random locations within each pasture prior to grazing in 1998. Cover of leafy spurge, grass, forbs, litter, and bare ground, and density of vegetative and flowering leafy spurge stems were measured before grazing in July 1998 and after grazing had begun in 1999 through 2002. Sampling was done by placing on the ground, at random, $40.2 \times 0.5 \mathrm{~m}$ frames inside and outside each exclosure. Leafy spurge flowering and vegetative stems were counted within each frame. Cover was estimated by species group (leafy spurge, grass, and forbs) and for bare ground and vegetative litter in the same frame using cover classes of $0 \%-5 \%, 6 \%-25 \%, 26 \%-50 \%, 51 \%-75 \%, 76 \%-$ $95 \%$, and $96 \%-100 \%$ of the ground covered (Daubenmire 1970). Aphthona densities were estimated using a sweep net in July 1999 through 2002. Sweep net sampling was used inside and outside each exclosure to determine the presence or absence of flea beetles. Three sweeps were used to cover approximately $1 \mathrm{~m}^{2}$ at 4 locations chosen at random inside and outside each exclosure. Aphthona were counted after each series of three sweeps.

Data were analyzed using a mixed model analysis of variance (ANOVA). The fixed model effects were site, year, grazing duration (season-long or rotation), and grazing treatment (with or without grazing). The random model effect was replication within each site $\times$ pasture $\times$ grazing duration $\times$ grazing treatment. The GLM procedure of SAS (1989) statistical software was used to perform the data analysis. The GLM procedure was used instead of the MIXED procedure because GLM provides greater decimal place accuracy for the degrees of freedom, and the form of the denominator for the approximate $F$-test is given in GLM but not MIXED. Exact $F$-tests based on the mean square error (MSE) were performed for testing the year and all year by duration and grazing treatment interaction hypotheses. Approximate F-tests (Montgomery 2001) were used to test for the significance of the main effect of grazing and for the duration by grazing treatment interaction. The denominators of the respective $F$-statistics were $0.7459 \times$ MS(rep) $+0.2541 \times$ MSE and $0.7468 \times$ MS(rep) $+0.2538 \times$ MSE where MS(rep) is the mean square for the nested replication (pasture $\times$ duration $\times$ grazing) effect. Data for leafy spurge vegetative and flowering density and Aphthona density were square root transformed to meet the ANOVA assumptions of normality and homogeneity of variance. For ease of interpretation, the observed means are presented. When an $F$-test was significant $(P<0.05)$, standard errors were used to determine differences among means. Standard errors were calculated by taking the square root of the quotient MSE/N, where MSE is the model mean square error and $N$ is the number of experimental units associated with each mean.

\section{RESULTS}

\section{Leafy Spurge}

Leafy Spurge Flowering Stem Density. The effect of grazing on leafy spurge flowering stem density depended on grazing

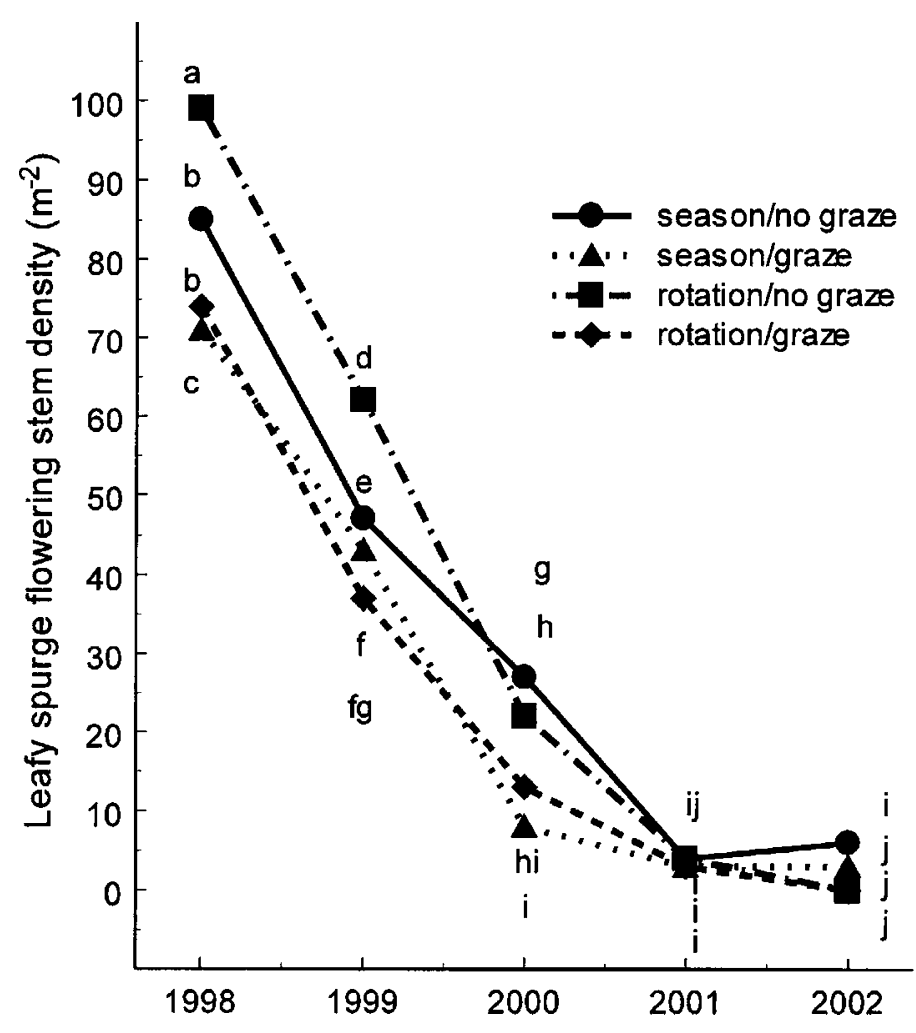

Figure 1. The interaction effect of grazing treatment (with or without), duration treatment (season-long or rotation), and year on leafy spurge flowering stem density. Different letters near means indicate differences in means among treatments within year and among years.

duration (season-long or rotational) and year $(P=0.0058)$. In 1998 before grazing started, leafy spurge flowering stem density was higher in all treatments compared to other years sampled (Fig. 1). Within 1998, flowering density was highest at 99 stems $\cdot \mathrm{m}^{-2}$ inside the exclosures of the rotation pastures, followed by inside the exclosures of the season-long pastures $\left(85\right.$ stems $\cdot \mathrm{m}^{-2}$ ), then outside the exclosures of the rotation pastures $\left(72 \mathrm{stem} \cdot \mathrm{m}^{-2}\right)$, and lowest outside the exclosures of the season-long pastures $\left(71 \mathrm{stems} \cdot \mathrm{m}^{-2}\right)$.

Flowering stem density decreased similarly in all treatments from 1998 to 1999 (Fig. 1). Flowering stem density was not different between grazing treatments. It was greater inside the exclosures of the rotation pastures than inside the exclosures of the season-long pastures. This trend continued in 2000 with the exception that flowering stems were the same inside and outside the exclosures in the rotation pastures, and there were more flowering stems inside the season-long exclosures than inside the rotation exclosures.

By 2001, flowering stem density was the same in all pastures and exclosures, and the same as flowering stem density outside the exclosures in both grazing treatments in 2000 (Fig. 1). There were no differences between treatments in 2002, except flowering stem density inside the exclosures of the season-long pastures $\left(6\right.$ stems $\left.\cdot \mathrm{m}^{-2}\right)$ was greater than the other treatments (Fig. 1).

Vegetative Stem Density. Grazing interacted with year to affect leafy spurge vegetative stem density $(P=0.0051)$. In 1998, vegetative stem density was the same inside (71 

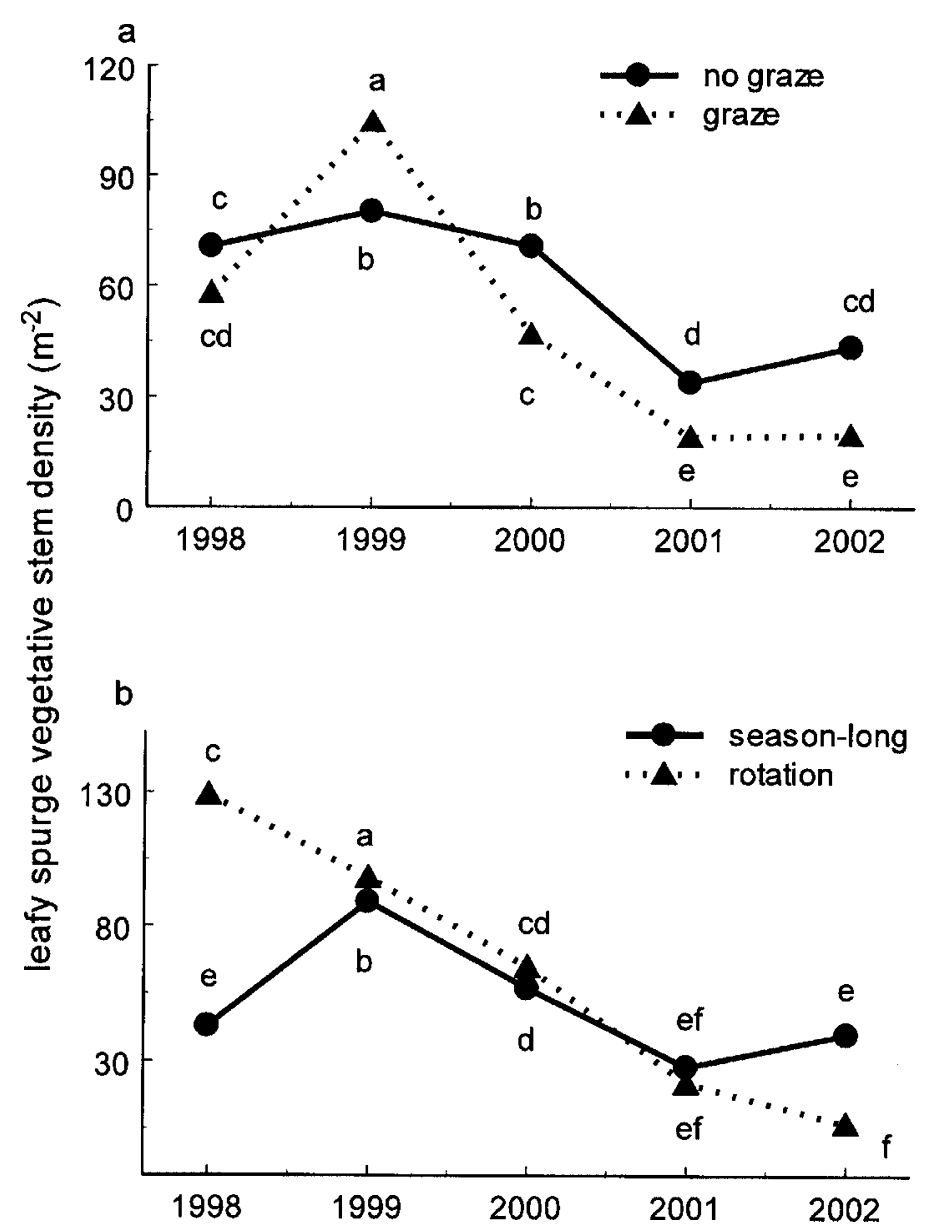

Figure 2. The two-way interaction effects of grazing treatment (with or without) and year (a), and duration treatment (season-long or rotation) and year (b) on leafy spurge vegetative stem density. Different letters near means indicate differences in means between treatments within year and among years.

stems $\left.\cdot \mathrm{m}^{-2}\right)$ and outside $\left(58\right.$ stems $\left.\cdot \mathrm{m}^{-2}\right)$ the exclosures (Fig 2a). In 1999, vegetative stem density increased overall, and the increase was greater where cows and sheep grazed (104 stems $\cdot \mathrm{m}^{-2}$ ) compared to where grazing was excluded $(80$ stems $\cdot \mathrm{m}^{-2}$ ). In 2000, where grazing was excluded, vegetative stem density was the same as 1999 . Grazing reduced vegetative stems to 1998 densities in 2000. Vegetative stem density decreased in 2001 regardless of whether there was grazing or not, and vegetative stem density was lower where grazed (19 stems $\cdot \mathrm{m}^{-2}$ ) compared to where grazing was excluded (34 stems $\left.\cdot \mathrm{m}^{-2}\right)$. Vegetative stem density was unchanged in 2002 compared to 2001.

Duration treatment (season-long or rotation) interacted with year to affect leafy spurge vegetative stem density $(P<0.0001)$. In 1998, there were more vegetative stems (127 stems $\cdot \mathrm{m}^{-2}$ ) in the rotation pastures than the seasonlong pastures (43 stems $\cdot \mathrm{m}^{-2}$, Fig $2 \mathrm{~b}$ ). In 1999 , vegetative stems increased in the season-long pastures and decreased in the rotation pastures. However, there were still more vegetative stems in the rotation pastures than the season-long pastures in 1999. Vegetative stem density decreased in 2000 and 2001, and there was no difference between duration treatments. Duration

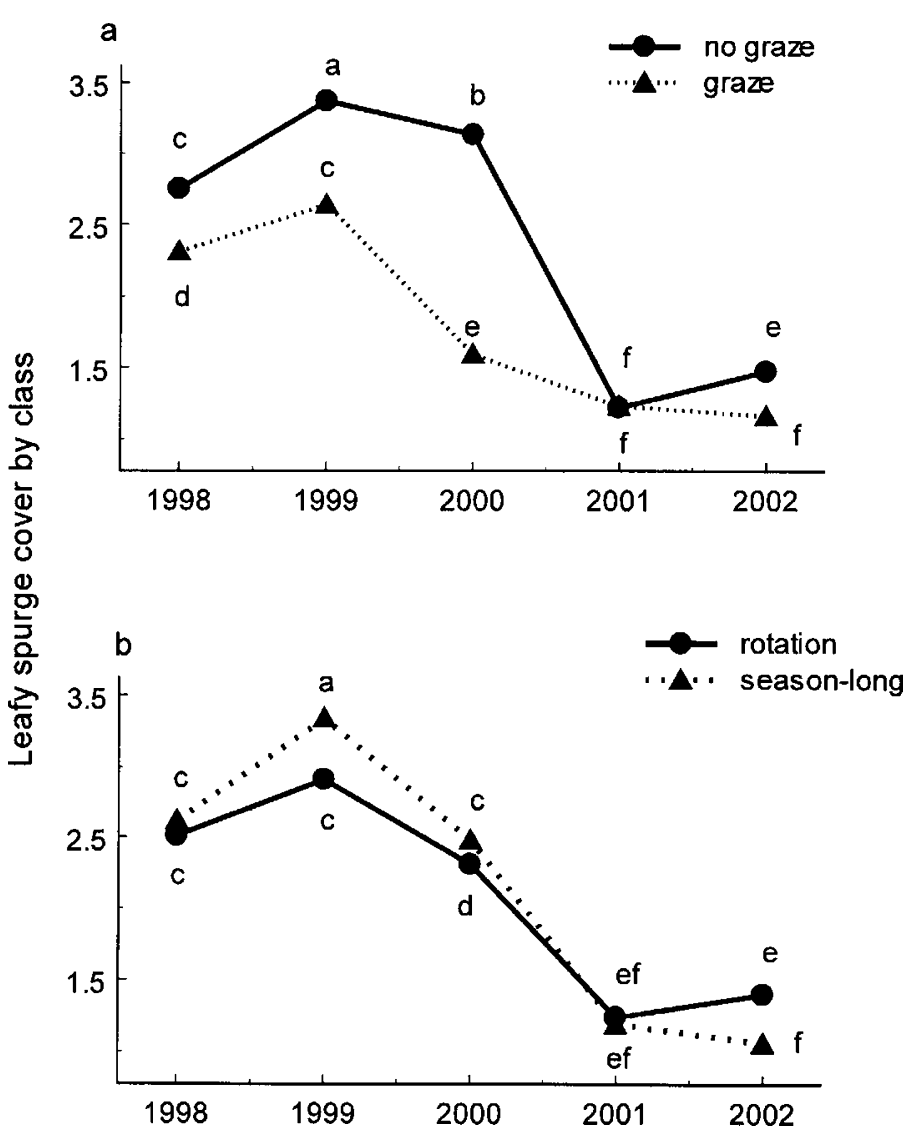

Figure 3. The two-way interaction effects of grazing treatment (with or without) and year (a), and duration treatment (season-long or rotation) and year (b) on leafy spurge cover by class $(1=0$ to $5,2=6$ to 25 , $3=26$ to $50,4=51$ to $75,5=76$ to 95 , and $6=96$ to 100). Different letters near means indicate differences in means between treatments within year and among years.

treatment did not affect vegetative stem density between 2001 and 2002 , but by 2002 , there were more vegetative stems in the season-long pastures $\left(40 \mathrm{stems} \cdot \mathrm{m}^{-2}\right)$ than the rotational pasture $\left(7 \mathrm{stems} \cdot \mathrm{m}^{-2}\right)$.

Leafy Spurge Cover. Grazing interacted with year to affect leafy spurge cover $(P<0.0001)$. In 1998 , cover was lower $(2.3$ cover class) outside the exclosures than inside the exclosures (2.7 cover class, Fig. 3a). Cover increased one year later but remained greater where grazing was excluded than where grazed. Cover decreased in 2000 and was lower where grazed compared to no grazing. In 2001, cover was lower than 2000, but grazing had no effect. By 2002, cover increased to 1.5 cover class where not grazed and decreased to 1.2 cover class where grazed.

The effect of duration treatment (season-long or rotation) on leafy spurge cover depended on year $(P=0.0011)$. Cover was the same ( 2.5 cover class) in 1998 and increased to 2.9 and 3.3 cover class in the rotation and season-long treatments, respectively, in 1999 (Fig 3b). In 2000, cover decreased to 1998 levels in the rotation treatment and was lower in the season-long treatment. Cover was lower in 2001 than all previous years, and there was no difference between duration treatments. Leafy spurge cover was 1.4 cover class in the 


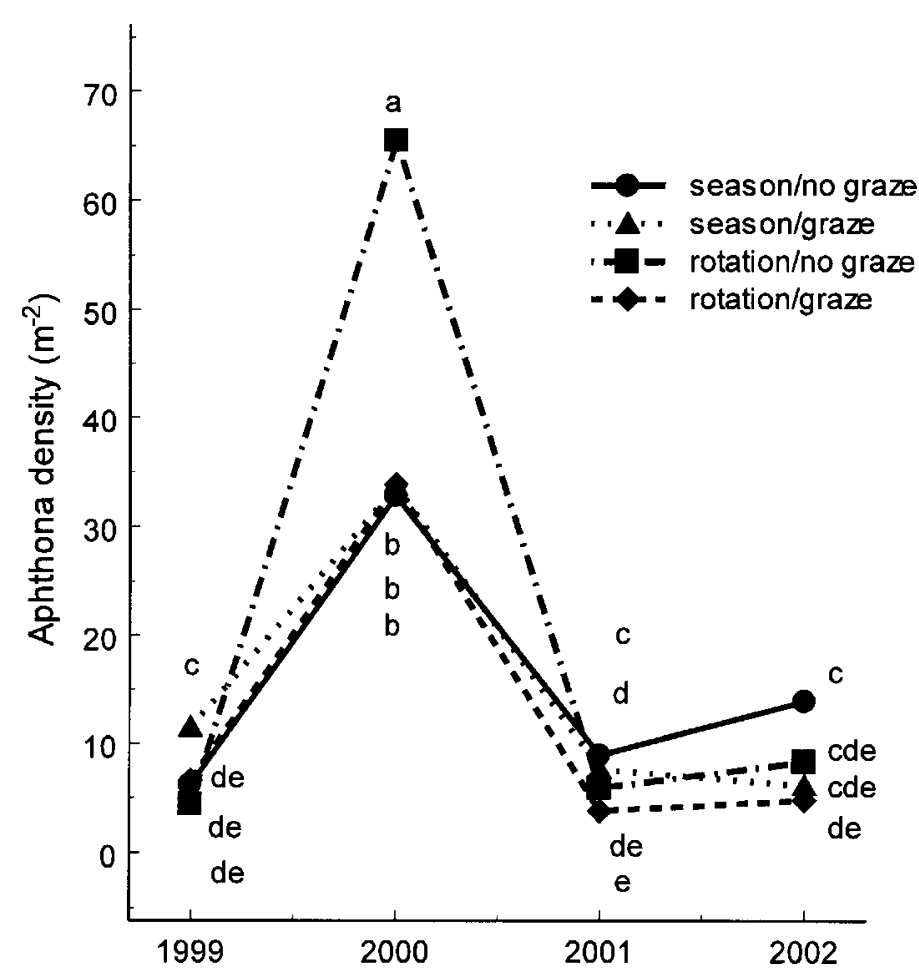

Figure 4. The interaction effect of grazing treatment (with or without), duration treatment (season-long or rotation), and year on Aphthona density. Different letters near means indicate differences in means among treatments within year and among years.

season-long pastures, which was greater than the rotation pastures (1.1 cover class) in 2002.

\section{Aphthona}

The effect of grazing on Aphthona density depended on duration and year $(P=0.0184)$. Aphthona numbers increased from about 6 insects $\cdot \mathrm{m}^{-2}$ in 1999 to about 33 insects $\cdot \mathrm{m}^{-2}$ in 2000 , but the greatest increase was where grazing was excluded in the rotation pastures $\left(65\right.$ insects $\cdot \mathrm{m}^{-2}$, Fig 4). Aphthona densities dropped to 1999 levels in all treatments in 2001, except Aphthona density was greater inside the exclosures of the season-long treatment in 2001 compared to 1999 and lower where grazed season-long in 2001 compared to 1998. Aphthona density was lower in the rotation pastures compared to where grazing was excluded in the season-long pastures in 2001, and the rotation grazed pastures had fewer flea beetles than the season-long grazed pastures in 2001. By 2002, Aphthona density was only lower in the rotation grazed pastures (5 insects $\cdot \mathrm{m}^{-2}$ ) compared to where season-long grazing was excluded $\left(13\right.$ insects $\left.\cdot \mathrm{m}^{-2}\right)$.

\section{Grass}

The duration grazing treatment did not affect grass cover $(P=0.7187)$. The effect of grazing was dependent on year $(P<0.0001)$. From 1998 through 2000, grass cover increased from 2.7 to 3.5 cover class where grazing was excluded (Fig. 5). Grass cover decreased from 2.9 to 2.6 cover class where grazed, and was less than where grazing was excluded over the same period. Grass cover decreased where grazing was excluded and increased where grazed from 2000 through 2002.

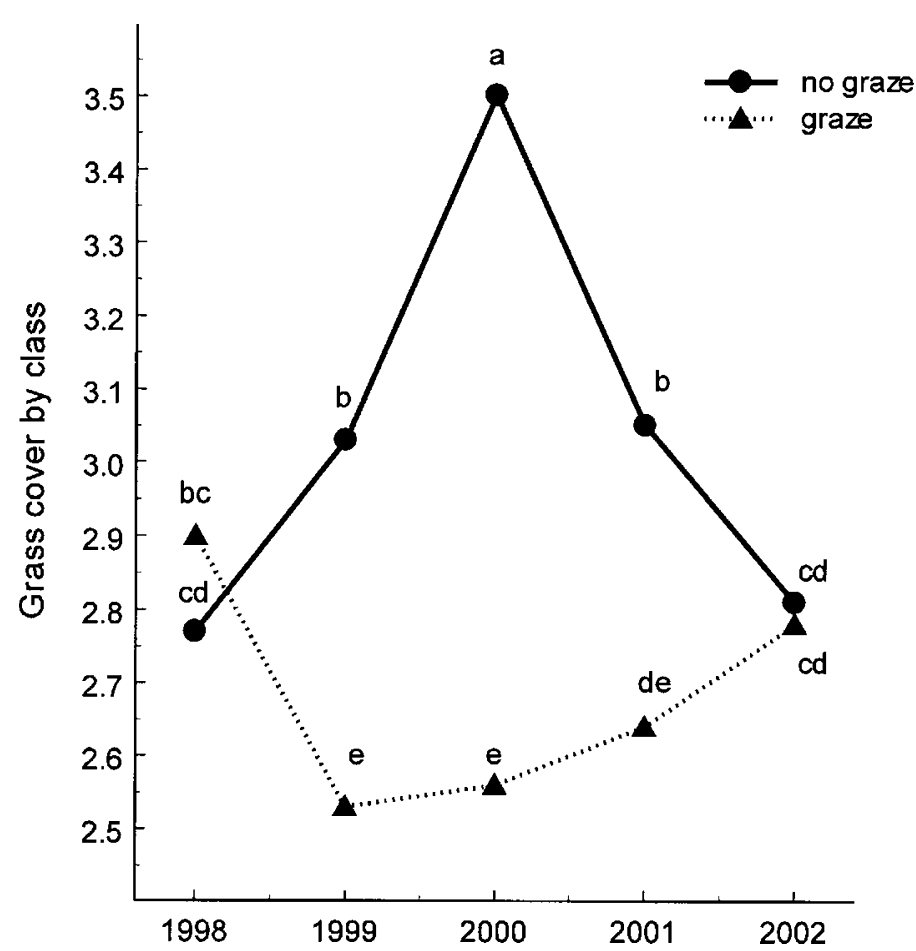

Figure 5. The interaction effect of grazing treatment (with or without) and year on grass cover by class $(1=0$ to $5,2=6$ to $25,3=26$ to 50 , $4=51$ to $75,5=76$ to 95 , and $6=96$ to 100 ). Different letters near means indicate differences in means between treatments within year and among years.

There was no difference in grass cover between grazing and no grazing in 2002.

\section{Forbs Other Than Leafy Spurge}

Forb cover was not affected by the grazing duration treatments $(P=0.0965)$, but was affected by the interaction of grazing and year $(P<0.0001)$. Forb cover decreased from 1998 to 1999 regardless of grazing treatment, but the decrease was greater (1.5 to 1.2 cover class) where grazing was excluded compared to where grazed (1.7 to 1.4 cover class, Fig. 6). In 2000, grazing continued to decrease forb cover, whereas forb cover increased dramatically where grazing was excluded. In 2001 , forb cover increased where grazed and decreased where grazing was excluded, but there was no significant difference between the two. By 2002, forb cover decreased where there was no grazing but remained the same where grazed.

\section{Litter}

The effect of grazing on litter cover depended on duration and year $(P=0.0147)$. Litter cover was the same inside and outside the exclosures in the season-long pastures (3.2 cover class) and lower than litter cover in the rotation pastures in 1998 (Fig. 7). Litter cover outside the exclosures $(4.7$ cover class) in the rotation pastures exceeded litter cover inside the exclosures (4.1 cover class) in 1998. In 1999, litter cover increased where grazing was excluded in both duration treatments and in the rotation pasture where cattle and sheep grazed. Litter decreased where the season-long pastures were grazed. Litter cover decreased and was the same in all treatments in 2000. In 


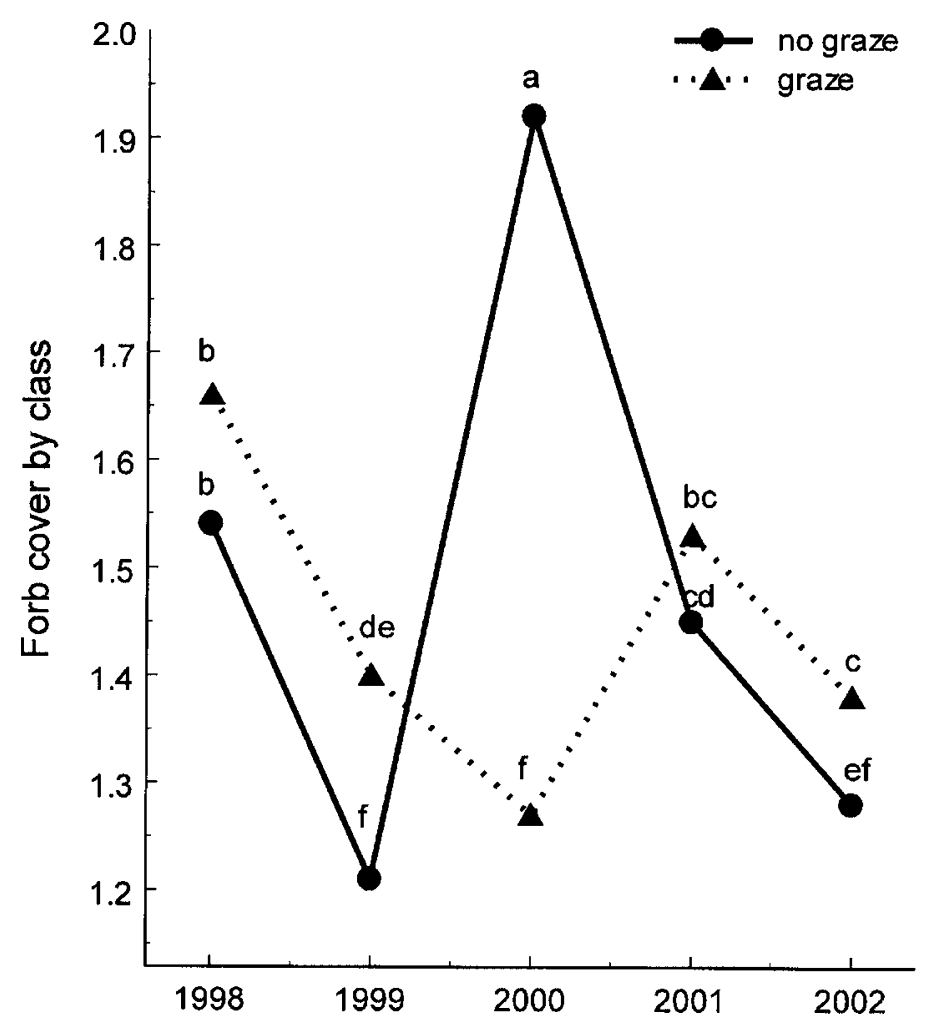

Figure 6. The interaction effect of grazing treatment (with or without) and year on forbs other than leafy spurge cover by class $(1=0$ to 5 , $2=6$ to $25,3=26$ to $50,4=51$ to $75,5=76$ to 95 , and $6=96$ to $100)$. Different letters near means indicate differences in means between treatments within year and among years.

2001, litter cover increased and was greatest where grazing was excluded in the rotation pastures, followed by grazed areas in the rotation pastures and grazing-excluded areas in the seasonlong pastures which were the same, and least in the grazed areas of the season-long pasture. In 2002, litter cover was higher where grazing was excluded ( 4.3 and 4.0 cover class) compared to grazing ( 3.5 cover class).

\section{Bare Ground}

The effect of grazing on bare ground cover depended on duration treatment and year $(P=0.0285)$. In 1998 , bare ground cover was greatest in the season-long pastures $(2.8$ cover class), followed by inside the exclosures in the rotation pastures (2.2 cover class), and lowest outside the exclosures of the rotation pastures (1.6 cover class, Fig. 8). Bare ground cover decreased in 1999 in all treatments except in the rotation grazing treatment. Bare ground continued to be higher in the season-long grazing treatment compared to the rotation treatment but there were no differences between inside and outside the exclosures. In 2000, bare ground cover was highest where grazed in the season-long pastures, followed by grazed in the rotation pastures which was the same as grazing-excluded areas in the season-long pastures, and lowest where grazing was excluded in the rotation pastures. In 2001, bare ground was greatest in the season-long grazing treatment, followed by the rotation grazing treatment, and lowest where grazing was excluded. In 2002, bare ground was greater where grazed

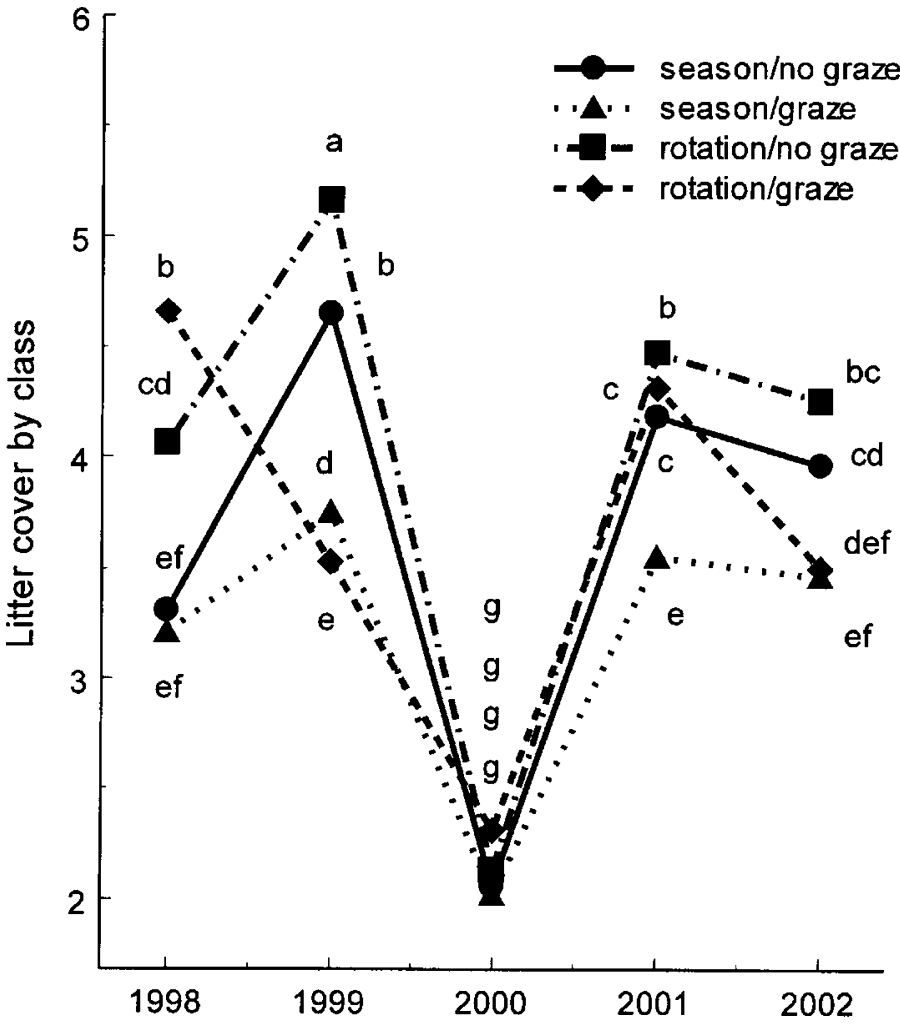

Figure 7. The interaction effect of grazing treatment (with or without), duration treatment (season-long or rotation), and year on plant litter cover by class $(1=0$ to $5,2=6$ to $25,3=26$ to $50,4=51$ to 75 , $5=76$ to 95 , and $6=96$ to 100 ). Different letters near means indicate differences in means among treatments within year and among years.

(1.3 and 1.9 cover class) compared to where grazing was excluded (1.3 and 1.0 cover class) except that bare ground was not different between rotation grazing and grazing excluded from the season-long treatment.

\section{DISCUSSION}

\section{Leafy Spurge Availability and Performance}

We found support for our hypothesis that combining cattle and sheep grazing with Aphthona would reduce leafy spurge density and cover more than Aphthona alone. Flowering stem density in 1999 and 2000 was lower where grazing was combined with Aphthona than Aphthona alone. Kirby et al. (2000) found that Aphthona alone reduced leafy spurge cover by $40 \%$ and density by over 200 stems $\cdot \mathrm{m}^{-2}$ seven years after release in east-central North Dakota. Sheep grazing alone also reduces leafy spurge density. Lacey and Sheley (1996) found sheep grazing reduced leafy spurge stems from about 200 to $125 \mathrm{stems} \cdot \mathrm{m}^{-2}$. In that study, combining sheep grazing with a single June application of picloram $\left(0.9 \mathrm{~kg} \cdot \mathrm{ha}^{-1}\right)$ reduced leafy spurge density from about 200 to 75 stems $\cdot \mathrm{m}^{-2}$ after 5 years. Our results show that combining cattle and sheep grazing with Aphthona reduced leafy spurge seed productive ability by about $94 \%$, and thus reduced species availability to colonize new sites in the plant community.

Combining ungulate grazing with insect grazing also caused a greater reduction of leafy spurge vegetative stem density and 
leafy spurge cover compared to insect grazing alone providing further support for our hypothesis. Hansen (1993) observed reduced leafy spurge densities with combined Aphthona and sheep grazing, and Beck and Rittenhouse (2000) found Aphthona and sheep management on leafy spurge infestations compatible. Our results show cattle, sheep, and Aphthona grazing were compatible, and may accelerate leafy spurge population decline compared to any applied alone. The steady decline of leafy spurge vegetative stem density suggests this management reduces leafy spurge availability and performance over time. Bardgett and Wardle (2003) suggest that, at the within-plant level, resource partitioning and resource use was complementary and maximized when herbivore species belong to multiple functional groups or guilds, which was the case in our study with sheep and Aphthona. Previous studies of aboveground and belowground herbivores on other plant species did not detect interactive effects (Masters and Brown 1992; Muller-Scharer and Brown 1995). Our results suggest that combining herbivores from different functional groups will cause a greater reduction in leafy spurge density and cover than a single functional group.

We found few consistent differences in leafy spurge flowering or vegetative stem density or cover between the two grazing duration treatments. Dahl (1999) found no difference in leafy spurge density between season-long or rotation sheep and cattle grazing after 2 years. Our results suggest that grazing with 2025 sheep on 45 ha for three and a half months will reduce leafy spurge no more than 45 to 50 sheep on pastures ranging from 25 to 79 ha for 3 weeks twice per season after 5 years. Grazing intensity and duration may affect grazing impacts on the plant community. Multiple defoliations of Idaho fescue (Festuca idahoensis Elmr.) increased spotted knapweed establishment and production (Jacobs and Sheley 1997; Jacobs and Sheley 1999). Lacey and Sheley (1996) reported reductions in leafy spurge using 1100 sheep on a 16 ha pasture for 2 days at a time. Depending on management needs and site conditions, grazing an unattended small band of sheep (25 to 50) on one pasture for long periods of time may be more practical than moving large bands with a herder over landscapes, grazing any area for only a few days. The short-duration, high-intensity grazing system may reduce sheep utilization of grass (Lacey and Sheley 1996). Our results, and the literature, suggest both grazing methods are effective in reducing leafy spurge availability and performance.

\section{Aphthona Density}

The grazing treatments in this study had little impact on Aphthona population density. In the long-term (5 years), the only difference we found was more Aphthona in the exclosures of the season-long pastures than the grazed rotation pastures. Lym (1998) reported that the establishment of Aphthona and their effect on leafy spurge was reduced in dense stands of leafy spurge. Aphthona embryonic development is temperature dependent (Fronasari 1995), and site characteristics (Kirby et al. 1999; Jacobs et al. 2001) or treatments (Lym et al. 1996) that increase soil temperature may improve establishment. The decrease in litter cover and the increase in bare ground we found after 5 years of combined ungulate and insect grazing did not increase Aphthona density in our study.

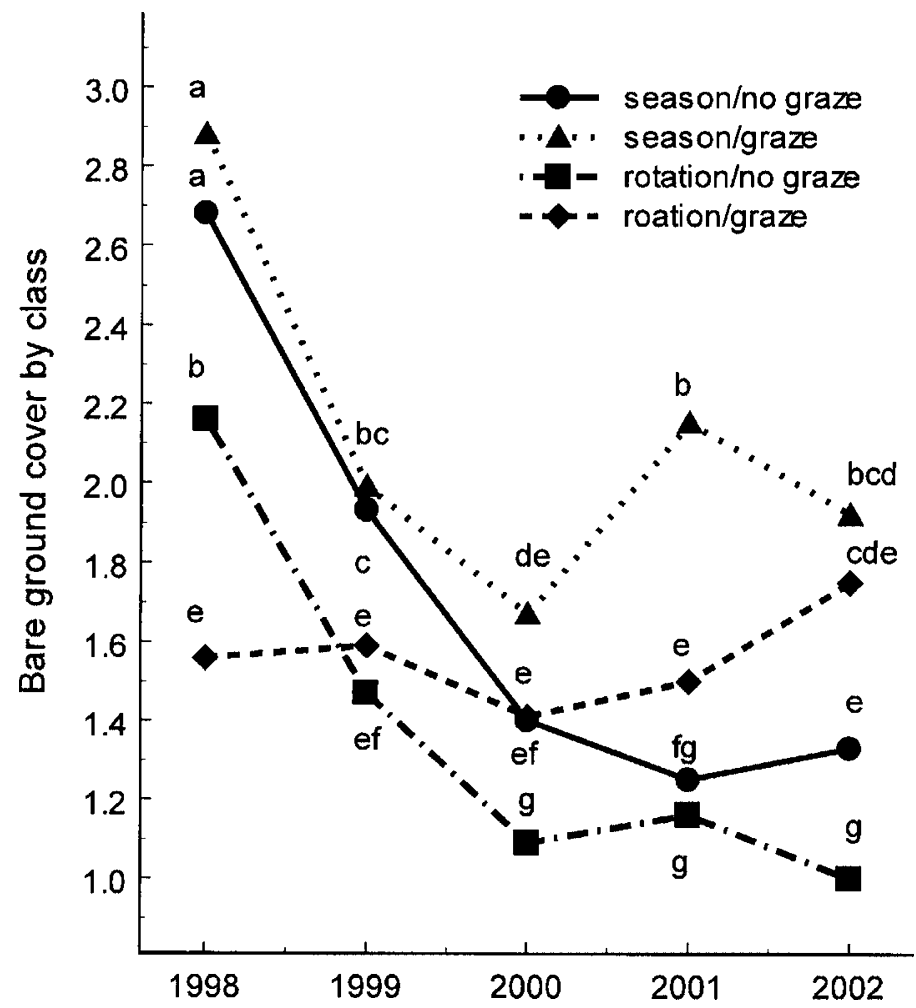

Figure 8. The interaction effect of grazing treatment (with or without), duration treatment (season-long or rotation), and year on bare ground cover by class ( $1=0$ to $5,2=6$ to $25,3=26$ to $50,4=51$ to 75 , $5=76$ to 95 , and $6=96$ to 100 ). Different letters near means indicate differences in means among treatments within year and among years.

\section{Desirable Species Performance}

The impact of weed management on desirable species is equally as important as the impact of weed management on the weed (Sheley et al. 1996). The land management objective where this study was conducted was cattle production, which is dependent on grass production. We used cover as an estimate of grass productivity. It is interesting that at the start and the end of our 5 -year sampling period, there was no difference in grass cover between the grazed and ungrazed areas, yet the change over time of each treatment was dramatically different. Probably the predominant factor influencing grass cover in 1998 in both treatments was leafy spurge. In 2002, we believe grazing and litter cover had the greatest influence on grass cover. Initially in the grazed pastures, cattle and sheep grazing reduced grass cover. Dahl (1999) found similar results after cattle and sheep grazed a leafy spurge-infested pasture for 2 years. Johnston and Peake (1960) found that sheep grazing alone on leafy spurgeinfested grassland increased crested wheatgrass cover. We can assume that the cattle were responsible for most of the grass cover reduction we observed. Where grazing was excluded, grass cover increased initially. This is similar to the grass response Kirby et al. (2000) reported where Aphthona were released in leafy spurge. However, by 2002, grass cover was the same as when it was suppressed by leafy spurge. We hypothesize that litter build-up suppressed grass performance in the absence of leafy spurge competition and grazing utilization, similar to that found by Lacey and Sheley (1996). Our litter 
data lend some support to this hypothesis. This suggests grazing by cattle is an important component of integrated management on leafy spurge-infested rangeland because it helps maintain grass performance.

It appears that forbs are highly variable and that factors other than our treatments may have a great influence on forb cover. For the most part, however, our forb cover data suggest that combining cattle and sheep grazing with Aphthona will not decrease the performance of this group of desirable species. This is important considering sheep consume forbs in addition to leafy spurge, and it is well recognized that increased plant diversity, through increased resource utilization, has a positive effect on production-driven processes (Bardgett and Wardle 2003).

\section{Site Availability}

We believe site availability was increased by the reduction of leafy spurge density by Aphthona and sheep and by reduced grass performance by cattle grazing. This notion is supported by the reduction in leafy spurge flowering stem density and increase in grass cover inside the exclosures. The data suggest only forbs other than leafy spurge were able to occupy available sites. If bare ground is a measure of site availability, then where ungulate and insect grazing were combined, sites became available for colonization. This implies that plant community diversity could be increased by introduction of desirable species propagules where ungulate and insect grazers are combined. The disturbance of grazing can also affect species availability and performance of belowground organisms, which can in turn affect the availability of aboveground organisms (Bardgett and Wardle 2003).

\section{IMPLICATIONS}

The results of this 5-year study indicate that combining $A p h$ thona with multispecies ungulate grazing may provide sustainable management of leafy spurge-infested grasslands. Aphthona attacks the above- and belowground parts of leafy spurge (Kirby et al.2000) while sheep grazing provides further impact on stems, leaves, and flowers. Cattle and sheep grazing at moderate stocking rates provided management of desirable species, which maintained their fitness, without affecting Aphthona.

\section{LITERATURE CITED}

Bardgett, R. D., and D. A. Wardle. 2003. Herbivore-mediated linkages between aboveground and belowground communities. Ecology 84:2258-2268.

Barker, W. T., and W. C. Whitman. 1989. Vegetation of the northern Great Plains. North Dakota Agricultural Research Report 111. Fargo, ND.

Beck, K. G., AND L. R. Rittenhouse. 2000. Leafy spurge management with sheep and flea beetles. Proceedings of the Western Society of Weed Science 53:48-49.

Bowes, G. G., AND A. G. Thomas. 1978. Longevity of leafy spurge seeds in the soil following various control programs. Journal of Range Management 31: 137-140.

DAHL, J. D. 1999. Effects of multi-species grazing on leafy spurge infested rangeland [thesis]. Fargo, ND: North Dakota State University. 67 p.

DaubenmiRe, R. 1970. Steppe vegetation of Washington. Washington Agricultural Experiment Statation Technical Bulliten No. 62. $131 \mathrm{p}$.

FronasARI, L. 1995. Life history of the flea beetle Aphthona abdominalis Duftschmid on Euphorbia esula L. (leafy spurge) in Italy. Biological Control 3:161-175.

Hansen, R. 1993. Effects of Aphthona flea beetles and sheep grazing in leafy spurge stands. In: K. G. Beck [ED.]. Proceedings of the Great Plains Agricultural Council Leafy Spurge Task Force Symposium; 26-28 July 1993; Silvercreek, CO: $p$ 47-48.

JaCoBs, J. S., AND R. L. Sheley. 1997. Relationships among Idaho fescue defoliation, soil water, and spotted knapweed establishment. Journal of Range Management 50:258-262.

JaCoBS, J. S., And R. L. Sheley. 1999. Grass defoliation intensity, frequency, and timing effects on spotted knapweed invasion. Journal of Range Management $52: 626-632$

Jacobs, J. S., R. L. Sheley, N. R. Spencer, and G. Anderson. 2001. Relationship among edaphic, climatic, and vegetation conditions at release sites and Aphthona nigriscutis population density. Biological Control 22:46-50.

Johnson, L. L., K. K. Sedivic, T. C. Faller, J. D. Dahl, and J. L. Dodd. 2002. Multispecies grazing on leafy spurge infested rangeland in southwestern North Dakota using rotational grazing. Hettinger Extension Research Center Report. Fargo, ND: North Dakota State University. $5 \mathrm{p}$.

Johnston, A., And R. W. Peake. 1960. Effect of selective grazing by sheep on control of leafy spurge. Journal of Range Management 12:192-195.

Kirby, D., M. Hayek, D. Cline, K. Krabbenhoft, and C. O'Brien. 1999. Site characteristics of flea beetle colonies in western North Dakota. Leafy Spurge Symposium Proceedings; 26-27 June 1999; Medora, ND. 24 p.

Kirby, D., R. B. Carlson, K. D. Krabbenhoft, D. Mundal, and M. M. Kirby. 2000. Biological control of leafy spurge with introduced flea beetles (Aphthona spp.). Journal of Range Management 53:305-308.

LACEY, J. R., AND R. L. Sheley. 1996. Leafy spurge and grass response to picloram and intensive grazing. Journal of Range Management 49:311-314.

Lajeunesse, S., R. Sheley, C. Duncan, and R. Lym. 1999. Leafy Spurge. In: R. L. Sheley and J. K. Petroff [EDS.]. Biology and management of noxious rangeland weeds. Corvallis, OR: Oregon State University Press. p 85-96.

LYM, R. G. 1998. The biology and integrated management of leafy spurge (Euphorbia esula) on North Dakota rangeland. Weed Technology 12:367-373.

Lym, R. G., R. B. Carson, C. G. Messersmith, and D. A. Mundal. 1996. Integration of herbicides with flea beetles, Aphthona nigriscutis, for leafy spurge control. In: V. C. Moran and J. H. Hoffmann [EDS.]. Proceedings of the IX International Symposium on Biological Control of Weeds; 19-26 January 1996; Stellenbosch, South Africa. University of Capetown. p 480-481.

Marrow, L. A. 1979. Studies on the reproductive biology of leafy spurge (Euphorbia esula). Weed Science 27:106-109.

Masters, G. J., AND V. K. Brown. 1992. Host-plant mediated interactions between spatially separated insects. Functional Ecology 6:175-179.

MontgomerY, D. C. 2001. Design and analysis of experiments. New York, NY: John Wiley and Sons. p 535-542.

Muller-Scherer, H., AND V. K. Brown. 1995. Direct and indirect effects of above and belowground insect herbivory on plant density and performance of Tripleurospermum perforatum during early plant succession. Oikos 72:36-41.

Pickett, S. T. A., S. L. Collins, and J. J. Armesto. 1987. Models, mechanisms, and pathways of succession. Botanical Review 53:335-371.

Prosser, C. W. 1994. Multispecies grazing of leafy spurge infested rangeland in North Dakota [thesis]. Fargo, ND: North Dakota State University. 88 p.

Raju, M. V. S., T. A. Steeves, and R. T. Coupland. 1963. Developmental studies on Euphorbia esula L. morphology and root system. Canadian Journal of Botany 41:579-589.

ReEs, N. 1994. The Aphthona pilot study. Proceedings of the leafy spurge symposium. 26-29 July 1994; Bozeman, MT: U.S. Dept. of Agriculture, Agricultural Research Service. $45 \mathrm{p}$.

Rees, N., P. C. Quimby, JR., G. L. Piper, E. M. Coombs, C. E. Turner, N. R. Spencer, AND L. V. KNUTSOn. 1996. Biological control of weeds in the west. Bozeman, MT: Western Weed Society of Weed Science. $332 \mathrm{p}$.

SAS. 1989. SAS/STAT User's Guide, Version 6. 4th Ed. Volume 2. Cary, NC: SAS Institute Inc. p 891-996.

Sheley, R. L., T. J. Svejcar, and B. D. Maxwell. 1996. A theoretical framework for developing successional weed management strategies on rangeland. Weed Technology 7:766-773.

Walker, R. H., And G. A. Buchanan. 1982. Crop manipulations in integrated weed management systems. Weed Science 30:17-24. 